\title{
Estimates of Soil Solution Ionic Strength and the Determination of pH in West Australian Soils
}

\author{
P. J. Dolling and G. S. P. Ritchie
}

\begin{abstract}
The average ionic strength of 20 West Australian soils was found to be $0 \cdot 0048$. The effects of three electrolytes (deionized water, $\mathrm{CaCl}_{2}$ and $\mathrm{KNO}_{3}$ ), three ionic strengths $(0 \cdot 03,0.005$ and soil ionic strength at field capacity, $\left.I_{\mathrm{s}}\right)$ and two soil liquid ratios $(1: 5$ and $1: 10)$ on the $\mathrm{pH}$ of 15 soils were investigated. $\mathrm{pH}$ measurements in solutions of ionic strength 0.005 differed the least from measurements made at $I_{\mathrm{s}}$. The differences that occurred in comparisons with distilled water or $\mathrm{CaCl}_{2}$ of ionic strength $0.03(0.01$ M) were much greater ( $\geq 0.4 \mathrm{pH}$ units). An extractant with an ionic strength of 0.005 may provide a more realistic measure of $\mathrm{pH}$ in the field than distilled water or $0.01 \mathrm{M} \mathrm{CaCl}_{2}$ for West Australian soils.
\end{abstract}

\section{Introduction}

The $\mathrm{pH}$ of a soil is an important parameter for assessing the suitability of a soil for the growth of plants. However, measurement of $\mathrm{pH}$ is fraught with difficulties (Russell 1973). Not only can soil variability cause large variations in $\mathrm{pH}$ within one paddock (up to $1 \mathrm{pH}$ unit; Russell 1973), but also the method of measurement can strongly influence the value obtained and the precision of that value (White 1969).

In Australia, soil $\mathrm{pH}$ has usually been determined in a 1:5 soil-water ratio but now $0.01 \mathrm{M} \mathrm{CaCl}_{2}$ (ionic strength of 0.03 ) is being used with increasing frequency (e.g. Williams 1980; Bromfield et al. 1983; Jarvis and Robson 1983; Vimpany and Bradley 1984). Schofield and Taylor (1955), White (1969) and Russell (1973) have suggested that the main criteria for selecting an extractant for $\mathrm{pH}$ measurement is that it should cause a minimum of disturbance to the distribution of ions between soil surfaces and the soil solution. An extractant that has the same ionic strength as the soil solution and is made up of the most common ions present in the soil may provide the most realistic $\mathrm{pH}$ measurement. However, such an approach would be very time consuming, as the ionic strength of each soil would have to be determined before $\mathrm{pH}$ measurement. A compromise would have to be achieved by using an ionic strength that represented the average value in a certain group of soils. Hence Gillman (1981), on the basis that some tropical soils have quite a low ionic strength (Gillman and Bell 1978), suggested that $\mathrm{pH}$ measurements at an ionic strength of 0.005 may be more realistic for the tropical soils he studied. However, the ionic strength of West Australian soils has not been measured, and so it is difficult to assess which medium would be the most appropriate for $\mathrm{pH}$ measurements. 
Consequently, the aim of this work was to estimate the ionic strength of West Australian soil solutions from both cultivated and uncultivated soils by using the relationship between $I_{\mathrm{s}}$ and electrical conductivity (Richards 1954; Griffin and Jurinak 1973; Gillman and Bell 1978). Subsequently, the $\mathrm{pH}$ of several soils, measured in commonly used media and at the average ionic strength determined above, were compared with the $\mathrm{pH}$ measured at the estimated ionic strength for each individual soil.

\section{Materials and Methods \\ Soils}

Surface samples from 20 soils were collected from the agricultural regions of Western Australia. Some of their properties are given in Table 1. Soils 1-10 are from virgin sites, whereas soils 11-20 are cultivated (mainly wheat-legume rotation). Samples of a lateritic podzolic soil (Table 1, soils 8 and 16-20) with similar histories of agricultural management, but which had been used for crop production for different lengths of time, were collected for ionic strength comparisons only. All the soils were airdried and sieved through a $2 \mathrm{~mm}$ mesh sieve before use.

\section{Ionic Strength Measurements}

The ionic strength of each soil was estimated by measuring the electrical conductivity of a $1: 5$ soilwater suspension. Triplicate samples were shaken for $16 \mathrm{~h}$, centrifuged and filtered before measuring the conductivity. The formula of Gillman and Bell (1978) was used to estimate the ionic strength of the soil solution at field capacity $\left(I_{\mathrm{s}}\right)$ :

$$
I_{s}=0.0446 \mathrm{C}-0.000173 \text {, }
$$

where $C$ is the electrical conductivity in $\mathrm{mS} \mathrm{cm}^{-1}$. The assumption that it was valid to use this equation for West Australian soils was tested by comparing the values for $I_{\mathrm{s}}$ estimated by using $C$ of a $1: 5$ soilwater mixture and $C$ of the soil solution at field capacity for four soils considered representative of those used in the study. $C$ at field capacity was measured by using the method of Gillman and Bell (1978) except that for each soil type, six centrifuge tubes (of $40 \mathrm{~g}$ soil capacity) were centrifuged at $3000 \mathrm{rpm}$ for 10 min after 8-9 days' incubation with deionized water. For soils $1,4,5$ and 6 the predicted values were $85,113,98$ and $89 \%$ of the measured values, respectively.

\section{pH Measurements}

The effects of deionized water, $\mathrm{CaCl}_{2}$ (at ionic strengths of $0.03,0.005$ and $I_{5}$ ) and $\mathrm{KNO}_{3}$ (at ionic strengths of 0.005 and $\left.I_{\mathrm{s}}\right)$ at two soililiquid ratios $(1: 5$ and $1: 10)$ on the $\mathrm{pH}$ of soils $1-10$ were investigated. The only exception was for soils 3-6; the pHs were not measured in $\mathrm{KNO}_{3}\left(I=I_{\mathrm{s}}\right)$ at a soil:liquid ratio of $1: 10$. This resulted in 56 different comparisons for studying the effect of soil:liquid ratio. Soils 11-15 were included to provide extra data for cultivated soils after an initial study into the effects of soil:liquid ratio and electrolyte type. Consequently, pHs of soils 11-15 were only determined in $\mathrm{CaCl}_{2}$ (at $I=I_{\mathrm{s}}, 0.005$ and 0.03 ) and water at a soil:liquid ratio of $1: 5$.

The electrolyte cations, soil:liquid ratios and 0.03 ionic strength were selected because of their common usage as media for $\mathrm{pH}$ measurements (White 1969). The ionic strength of the soil was chosen because it was thought to cause the least disturbance of the distribution of ions in the soil. An ionic strength of 0.005 was selected on the basis of the average ionic strength determined in the other part of this work. Triplicate samples of each soil were shaken for $16 \mathrm{~h}$ with each treatment and then centrifuged and filtered to produce a clear supernatant liquid. $\mathrm{pH}$ measurements were made with a Radiometer PHM64 Research pH meter, using a combination electrode immersed in the supernatant solution. $\mathrm{pH}$ readings were taken after the rate of change of $\mathrm{pH}<0.015$ per $90 \mathrm{~s}$ interval.

\section{Results}

\section{Ionic Strength of the Soil Solution}

Of the 20 soils $14 \mathrm{had}$ an estimated ionic strength $<0 \cdot 0053$, reflecting the generally low fertility and buffer capacity of West Australian soils (Table 1). 


\begin{tabular}{|c|c|c|c|c|c|c|c|c|c|c|}
\hline \multirow[b]{3}{*}{ No. } & \multirow[b]{3}{*}{ Soil $^{\mathrm{A}}$} & \multirow[b]{3}{*}{ Great Soil Group } & \multirow{3}{*}{$\begin{array}{l}\text { Northcote } \\
\text { classification }\end{array}$} & \multirow{3}{*}{$\begin{array}{c}\text { Organic } \\
\text { matter }(\%)\end{array}$} & \multirow{3}{*}{$\begin{array}{c}C E C \\
\left(\mathrm{C} \mathrm{g}^{-1}\right)\end{array}$} & \multirow[b]{3}{*}{$10^{3} \times I_{s}$} & \multicolumn{4}{|c|}{$\mathrm{pH}^{\mathrm{B}}$} \\
\hline & & & & & & & \multirow{2}{*}{$\begin{array}{l}\text { Distilled } \\
\text { water }\end{array}$} & \multicolumn{3}{|c|}{$\mathrm{CaCl}_{2}$} \\
\hline & & & & & & & & $I_{\mathrm{s}}^{\mathrm{c}}$ & $I_{0-00 s}$ & $I_{0.03}$ \\
\hline 1 & Lancelin & siliceous sand & Uc $5 \cdot 1$ & $1 \cdot 3$ & $8 \cdot 0$ & $2 \cdot 0 \pm 0 \cdot 3$ & $5 \cdot 83$ & $5 \cdot 8$ & $5 \cdot 30$ & $5 \cdot 11$ \\
\hline 2 & Warranine & non-calcic brown & Dr $2 \cdot 11$ & $5 \cdot 95$ & $31 \cdot 0$ & $3 \cdot 7 \pm 0 \cdot 2$ & $7 \cdot 34$ & $6 \cdot 46$ & $6 \cdot 34$ & $6 \cdot 06$ \\
\hline 3 & Kojonup & gleyed podzolic & Dy $5 \cdot 81$ & $2 \cdot 14$ & $6 \cdot 0$ & $1 \cdot 2 \pm 0 \cdot 1$ & $5 \cdot 80$ & $5 \cdot 48$ & $5 \cdot 13$ & $4 \cdot 84$ \\
\hline 4 & Balkuling & lateritic podzolic & Dy $5 \cdot 51$ & $4 \cdot 92$ & $11 \cdot 2$ & $2 \cdot 3 \pm 0 \cdot 1$ & $6 \cdot 12$ & $5 \cdot 53$ & $5 \cdot 48$ & $5 \cdot 15$ \\
\hline 5 & Malebelling & yellow podzolic & $\mathrm{Gn} 2 \cdot 44$ & $3 \cdot 04$ & $8 \cdot 0$ & $5 \cdot 3 \pm 0 \cdot 2$ & $5 \cdot 73$ & $5 \cdot 43$ & $5 \cdot 28$ & $4 \cdot 97$ \\
\hline 6 & Yalanbee & lateritic podzolic & KS-Uc $4 \cdot 21$ & $2 \cdot 46$ & $6 \cdot 0$ & $1 \cdot \overrightarrow{0 \pm 0} \cdot 1$ & $5 \cdot 97$ & $5 \cdot 84$ & $5 \cdot 17$ & $4 \cdot 85$ \\
\hline 7 & Merredin (subsoil) & yellow earth & $\operatorname{Gn} 2 \cdot 24$ & 0.09 & $1 \cdot 2$ & $2 \cdot 4 \pm 0 \cdot 3$ & $4 \cdot 51$ & $4 \cdot 35$ & $4 \cdot 19$ & $4 \cdot 07$ \\
\hline 8 & Gairdner River & lateritic podzolic & Dy $5 \cdot 51$ & $1 \cdot 85$ & - & $3 \cdot 5 \pm 0 \cdot 2$ & $5 \cdot 16$ & $4 \cdot 88$ & $4 \cdot 76$ & $4 \cdot 50$ \\
\hline 9 & Merredin & yellow earth & $\operatorname{Gn} 2 \cdot 24$ & 1.49 & $3 \cdot 0$ & $14 \cdot 9 \pm 0 \cdot 2$ & $6 \cdot 22$ & $5 \cdot 60$ & $5 \cdot 88$ & $5 \cdot 48$ \\
\hline 10 & Badgingarra & earthy sand & Uc $5 \cdot 2$ & 0.83 & $3 \cdot 2$ & $1 \cdot 5 \pm 0 \cdot 1$ & $6 \cdot 00$ & $5 \cdot 31$ & $5 \cdot 04$ & $4 \cdot 67$ \\
\hline 11 & York & non-calcic brown & Dr $2 \cdot 22$ & $4 \cdot 33$ & $21 \cdot 9$ & $7 \cdot 6 \pm 0 \cdot 1$ & $5 \cdot 94$ & $5 \cdot 54$ & $5 \cdot 64$ & $5 \cdot 40$ \\
\hline 12 & Waroona $\mathbf{A}$ & alluvial & Gn $3 \cdot 42$ & $5 \cdot 62$ & $10 \cdot 0$ & $6 \cdot 6 \pm 0 \cdot 02$ & $4 \cdot 96$ & $4 \cdot 55$ & $4 \cdot 60$ & $4 \cdot 26$ \\
\hline 13 & Roleystone & yellow podzolic & Dy $4 \cdot 61$ & $8 \cdot 01$ & $7 \cdot 0$ & $2 \cdot 3 \pm 0 \cdot 05$ & $5 \cdot 60$ & $5 \cdot 14$ & $5 \cdot 02$ & $4 \cdot 66$ \\
\hline 14 & Waroona B & gleyed lateritic podzolic & Dy $5 \cdot 81$ & $2 \cdot 15$ & $2 \cdot 0$ & $1 \cdot 7 \pm 0 \cdot 006$ & $4 \cdot 99$ & $4 \cdot 38$ & $4 \cdot 30$ & $4 \cdot 07$ \\
\hline 15 & Beverley & red earth & Gn $2 \cdot 14$ & $1 \cdot 46$ & $10 \cdot 0$ & $3 \cdot 2 \pm 0 \cdot 006$ & $6 \cdot 65$ & $5 \cdot 97$ & $5 \cdot 89$ & $5 \cdot 53$ \\
\hline 16 & GR $3^{\circ}$ & lateritic podzolic & Dy $5 \cdot 51$ & $1 \cdot 66$ & - & $3 \cdot 9 \pm 0 \cdot 82$ & 一 & - & - & - \\
\hline 17 & GR 8 & lateritic podzolic & Dy $5 \cdot 51$ & $2 \cdot 20$ & - & $4 \cdot 8 \pm 0 \cdot 12$ & - & - & - & - \\
\hline 18 & GR 11 & lateritic podzolic & Dy $5 \cdot 51$ & $2 \cdot 38$ & - & $8 \cdot 3 \pm 0 \cdot 34$ & - & - & - & - \\
\hline 19 & GR 15 & lateritic podzolic & Dy $5 \cdot 51$ & $3 \cdot 46$ & - & $9 \cdot 6 \pm 0 \cdot 18$ & - & - & - & - \\
\hline 20 & GR 25 & lateritic podzolic & Dy $5 \cdot 51$ & $3 \cdot 34$ & - & $9 \cdot \overline{1 \pm 0} 0 \cdot 44$ & - & - & - & - \\
\hline
\end{tabular}

${ }^{\text {A Soils }}$ 11-20 are cultivated soils. All soils sampled from 0-10 cm depth except No. 7 (30-60 cm depth).

${ }^{B}$ 1:5 soil liquid ratio.

${ }^{c} I_{\mathrm{s}}$ estimated from equation 1.

${ }^{D}$ Number refers to years of cultivation. 
The average estimated $I_{\mathrm{s}}$ for all the soils was $0 \cdot 0048$, similar to the value found by Gillman and Bell (1978) for North Queensland soils. For the 10 cultivated soils, the average estimated $I_{\mathrm{s}}$ was 0.0057 , whereas the average for the virgin soils was 0.0038 . Even though there was an increase in the ionic strength of the soil solution with years of cultivation (Table 1 , soils $8,16-20$ ), it is not a marked effect and appears to reach a maximum after about 15 years.

\section{pH Measurements}

Examples of the variation of $\mathrm{pH}$ measured in deionized water and $\mathrm{CaCl}_{2}$ solutions are given in Table 1.

Table 2. The mean difference in $\mathrm{pH}$ measured by different soil treatments

\begin{tabular}{|c|c|c|c|c|}
\hline Extractant & $\begin{array}{c}\text { Soil- } \\
\text { liquid } \\
\text { ratio }\end{array}$ & $\triangle \mathrm{pH}^{\mathrm{A}, \mathrm{D}}$ & $\Delta \mathrm{pH}_{\mathrm{ca}}^{\mathrm{B}, \mathrm{D}}$ & $\Delta \mathrm{pH}_{\mathrm{k}}^{\mathrm{C}, \mathrm{D}}$ \\
\hline Distilled water & $\begin{array}{l}1: 5 \\
1: 10\end{array}$ & $0 \cdot 15 \pm 0 \cdot 10(5)$ & $\begin{array}{l}0 \cdot 44 \pm 0 \cdot 24(1)^{\mathrm{E}} \\
0 \cdot 48 \pm 0 \cdot 20(1)\end{array}$ & $\begin{array}{l}0 \cdot 30 \pm 0 \cdot 23(1) \\
0 \cdot 41 \pm 0 \cdot 19(0)\end{array}$ \\
\hline$I_{0.005} \mathrm{CaCl}_{2}$ & $\begin{array}{l}1: 5 \\
1: 10\end{array}$ & $0.06 \pm 0.07(7)$ & $\begin{array}{l}0 \cdot 20 \pm 0 \cdot 18(1)^{\mathrm{E}} \\
0 \cdot 21 \pm 0 \cdot 62(2)\end{array}$ & - \\
\hline$I_{0.005} \mathrm{KNO}_{3}$ & $\begin{array}{l}1: 5 \\
1: 10\end{array}$ & $0.12 \pm 0.07(3)$ & - & $\begin{array}{l}0 \cdot 26 \pm 0 \cdot 19(0) \\
0 \cdot 13 \pm 0 \cdot 10(0)\end{array}$ \\
\hline$I_{0.03} \mathrm{CaCl}_{2}$ & $\begin{array}{l}1: 5 \\
1: 10\end{array}$ & $0.09 \pm 0.08(4)$ & $\begin{array}{l}0 \cdot 46 \pm 0 \cdot 22(0)^{\mathrm{E}} \\
0 \cdot 39 \pm 0 \cdot 17(0)\end{array}$ & $\begin{array}{l}0 \cdot 65 \pm 0 \cdot 19(0) \\
0 \cdot 52 \pm 0 \cdot 25(0)\end{array}$ \\
\hline$I_{\mathrm{s}} \mathrm{CaCl}_{2}$ & $\begin{array}{l}1: 5 \\
1: 10\end{array}$ & $0 \cdot 10 \pm 0 \cdot 11(5)$ & - & $\begin{array}{l}0 \cdot 15 \pm 0 \cdot 11(3) \\
0 \cdot 13 \pm 0 \cdot 12(3)\end{array}$ \\
\hline$I_{\mathrm{s}} \mathrm{KNO}_{3}$ & $\begin{array}{l}1: 5 \\
1: 10\end{array}$ & $0.09 \pm 0.05(1)$ & $\begin{array}{l}0 \cdot 15 \pm 0 \cdot 11(3) \\
0 \cdot 13 \pm 0 \cdot 12(3)\end{array}$ & - \\
\hline
\end{tabular}

A $\triangle \mathrm{pH}$ : the difference in $\mathrm{pH}$ between the $1: 10$ and $1: 5$ soil liquid ratios for each solution.

в $\triangle \mathrm{pH}_{\mathrm{ca}}$ : the difference in $\mathrm{pH}$ between measurements in $\mathrm{CaCl}_{2}$ at $I=I_{\mathrm{s}}$ and other treatments.

$C \triangle \mathrm{pH}_{\mathrm{k}}$ : Same as $\mathrm{B}$ except $\mathrm{KNO}_{3}$ is the solution.

D All $\triangle \mathrm{pH}$ values are the mean for soils $1-10 \pm$ standard deviation. Figures in brackets refer to the number of soils for which $\triangle \mathrm{pH}$ is not significant at $P<0.05$.

E As for $\mathrm{D}$ except the $\triangle \mathrm{pH}$ values are the mean of soils $1-15$.

\section{Effect of Soil:Liquid Ratio}

For all the treatments used (except distilled water) the difference in $\mathrm{pH}$ determined from the two soil:liquid ratios was $\leqslant 0.12 \mathrm{pH}$ units (Table 2). The differences were not statistically significant $(P<0.05)$ for 24 of the 56 possible comparisons. It would appear that changes in the soil:liquid ratio of $\leqslant 50 \%$ do not have a large effect on $\mathrm{pH}$ measurements.

\section{Effect of Extractant Type and Ionic Strength}

For the purposes of this investigation, the $\mathrm{pH}$ measured in media with the same ionic strength as the soil $\left(I_{\mathrm{s}}\right)$ will be compared with the other treatments. 
The smallest difference in $\mathrm{pH}$ was observed between the $\mathrm{CaCl}_{2}$ and $\mathrm{KNO}_{3}$ media both at $I=I_{s}$ (Table 2), indicating that at constant ionic strength, changes in $\mathrm{pH}$ due to type of electrolyte were not a major factor.

The average $\mathrm{pH}$ difference between $\mathrm{CaCl}_{2}$ at $I=I_{\mathrm{s}}$ and other measurements was in the order (Table 2):

$$
0.03 \mathrm{CaCl}_{2}>\text { water }>0.005 \mathrm{CaCl}_{2}>I_{s}, \mathrm{KNO}_{3} \text {. }
$$

The same trend was observed for the $\mathrm{pH}$ difference between $\mathrm{KNO}_{3}$ at $I=I_{\mathrm{s}}$ and other treatments (Table 2). As anticipated from the results of previous work (reviewed by White 1969), the variation in the ionic strength of the media appears to be the major contributor to $\mathrm{pH}$ differences measured by the different treatments.

\section{Discussion and Conclusions}

$\mathrm{pH}$ measurements in solutions of $I=0.005$ differed the least from measurements made in solutions of ionic strength equal to that of the soil. Even though the $\mathrm{pH}$ values at $I_{\mathrm{s}}$ and $I=0.005$ were significantly different, the difference was less than that which occurs from soil variability. On the other hand, the differences that occurred in comparisons with distilled water or $0.01 \mathrm{M} \mathrm{CaCl}_{2}$ were much greater ( $\leqslant 0.4 \mathrm{pH}$ units).

If changes are to be made in the most commonly used method for $\mathrm{pH}$ measurement in Australia and the criteria for its choice is that it causes the least disturbance of the distribution of ions in the soil, then it would appear that $0.01 \mathrm{M}$ $\mathrm{CaCl}_{2}$ shows no distinct improvement over distilled water as a medium for $\mathrm{pH}$ measurement in West Australian soils. An extractant of $I=0.005$ may provide a more realistic compromise. This is similar to Gillman's (1981) findings, even though the soils he studied (acrohumoxs, an eutrostox and a haplustox) are not common agricultural soils in Western Australia. $\mathrm{CaCl}_{2}$ would probably be the most suitable electrolyte because of the dominance of $\mathrm{Ca}$ in most agricultural soils.

\section{Acknowledgments}

We would like to thank Mrs T. Anning for technical assistance and Mr W. L. Crabtree for providing the Gairdner River soils samples.

\section{References}

Bromfield, S. M., Cumming, R. W. M., David, D. J., and Williams, C. H. (1983). Changes in soil pH, manganese and aluminium under subterranean clover pasture. Aust J. Exp. Agric. Anim. Husb. 23, 181-91.

Gillman, G. P. (1981). Analytical methods. Varisol No. 1, 7-8.

Gillman, G. P. and Bell, L. C. (1978). Solution studies on weathered soils from tropical north Queensland. Aust J. Soil Res. 16, 67-77.

Griffin, R. A., and Jurinak, J. J. (1973). Estimation of activity coefficients from the electrical conductivity of natural aquatic systems and soil extracts. Soil Sci. 116, 26-30.

Jarvis, S. C., and Robson, A. D. (1983). The effect of nitrogen nutrition of plants on the development of acidity in West Australian soils. I. Effects with subterranean clover grown under leaching conditions. Aust. J. Agric. Res. 34, 341-53.

Richards, L. A. (1954). 'Diagnosis and Improvement of Saline and Alkali Soils.' Agric. Handb. No. 60. (U.S. Dep. Agric.: Washington.)

Russell, E. W. (1973), 'Soil Conditions and Plant Growth.' (Longman:London.)

Schofield, R. K., and Taylor, A. W. (1955). The measurement of soil pH. Proc. Soil Sci. Soc. Am. 19, $164-7$. 
Vimpany, I., and Bradley, J. (1984). Lime requirement of acid soils. Proc. Natn. Soils Conf., Brisbane, Australia p. 309.

White, R. E. (1969). Measurement of soil pH. J. Aust. Inst. Agric. Sci. 35, 3-15.

Williams, C. H. (1980). Soil acidification under clover pasture. Aust. J. Exp. Agric. Anim. Husb. 20, 561-7. 